\title{
Pedagogical Beliefs about Critical Thinking among Indonesian Mathematics Pre-service Teachers
}

\section{Kusaeri}

Dr., Universitas Islam Negeri Sunan Ampel Surabaya, Indonesia, kusaeri@ uinsby.ac.id

\section{Anindito Aditomo}

Dr., Humboldt Postdoctoral Fellow, DIPF Germany, and University of Surabaya, Indonesia,aditomo@staff.ubaya.ac.id

This study aims to (1) measure pre-service teachers' pedagogical belief in the value of teaching Critical Thinking (CT), their preparedness to teach CT, and their preference toward constructivist teaching approaches to develop students' CT skills; and (2) explore the potential links between these pedagogical beliefs and aspects of teacher education experience. Participants were 223 mathematics preservice teachers from 3 teacher education institutions in East Java, Indonesia. Beliefs about the value of teaching CT and perceived readiness to teach CT were measured using Likert-type scales, while preference towards constructivist instruction was assessed using vignettes depicting teaching dilemmas. Participants believed that some CT skills (thinking independently and logical communication) were important, but CT dispositions were not. About $60 \%$ believed they are prepared to teach CT and generally preferred constructivist over traditional instruction. Most aspects of the pre-service education were not associated with pedagogical beliefs about CT disposition, perceived preparedness, or preference for constructivist instruction, while some were only weakly associated with belief about teaching CT skills. These highlight the need for mathematics teacher educators to give more emphasis on the importance of $\mathrm{CT}$, especially its dispositional dimensions, and the role of constructivist instruction in developing CT.

Keywords: critical thinking, pedagogical beliefs, mathematics education, pre-service teachers, thinking disposition

\section{INTRODUCTION}

Improving the quality of mathematics teaching is a strategic issue which focuses on curriculum reform across the globe in the last three decades (Fung et al., 2017; Lee et 
al., 2017; Lui \& Bonner, 2016; Sembiring et al., 2008). This reform is directed at how mathematical teaching and learning can challenge and develop students' thinking skills (Zohar \& Schwartzer, 2005). This issue has been discussed for decades as it can be traced back in 1938, when Dewey highlighted the importance of teaching and learning that emphasizes the development of students' thinking (Ab Kadir, 2015). It can be realized used a critical thinking.

Critical thinking re-emerges as a component to prepare the 21 st century generations to survive with the changing era (Berliner, 2009). A number of studies (As'ari et al., 2017; Innabi \& El Sheikh, 2007; Staples \& Truxaw, 2012) conclude that mathematics has a potential role in developing critical thinking skills. In this regard, mathematics teachers have a strategic role to help their students to develop their critical thinking skills. Teachers must be able to give students opportunities to understand the concepts and make justifications in their mathematics learning, not a learning that merely trains students to apply the formula and mathematical procedures.

Teaching and learning that only emphasize the application of mathematics formulas and procedures can lead to students' weak reasoning and logic. As a reflection, international surveys such as PISA (Program for International Student Assessment) and TIMSS (Trends in International Mathematics and Science Study) always show that Indonesian students' mathematics achievement is always below those from other developing countries (Oktiningrum \& Hartono, 2016). Since joining PISA in 2000 up to 2015, Indonesian students are always in the low rank in terms of their mathematic achievement. In the TIMSS survey, Indonesian students' mathematics achievement is also alarming (Lailiyah et al., 2018). One of the contributing factors to the low PISA and TIMSS results is that students are not accustomed to solving mathematics problems that demand critical thinking skills (Nursyahidah \& Albab, 2017).

The studies conducted by Sembiring et al. (2008) and Dewantara et al. (2015) found that teachers often provide students with mathematics problem that mostly require students to apply formulas, procedures or algorithms. In their interaction with students, teachers also commonly start with questions that focus only on formulas that require students to respond shortly. This condition, according to Hallman-Thrasher (2017) may fail to encourage students to reason and construct arguments. They will be confused when confronted with the typical mathematics problems in PISA and TIMSS that require high reasoning and involve all levels of thinking from Bloom's taxonomy to solve.

Changing the existing mindset of the mathematics teachers to become a critical thinker is not unproblematic. Various studies have tried to provide intervention programs to facilitate mathematics teachers to change their mindset and become critical thinkers (Hammerness et al., 2005; Richardson \& Placier, 2001). However, the programs seem to bring no significant influence and the result is contrary to the expectation. Such a nonperformance may be caused by the teachers' beliefs. Grootenboer (2008) states that teachers' mindset is closely related to their beliefs. The beliefs are established, difficult to change and can influence the teacher's views in teaching mathematics (Cooney, 2001). Hence, training the pre-service teachers to be critical thinkers can be the right choice rather than providing intervention programs for the in-service teachers 
(Prahmana et al., 2012). In this context, it is important to explore pre-service teachers' beliefs as one of the significant aspects of teacher candidates.

The beliefs of a pre-service teacher relate to her or his knowledge and will filter out all the new information so as to shape the mindset (Lui \& Bonner, 2016). Pre-service teachers who have high confidence tend claim that the cause of students' failure in solving mathematics problems is lack of effort. On the contrary, pre-service teachers with the same ability but have a lower confidence commonly assume that the failure results from the lack of students' ability. This mindset, according to Skilling et al. (2016), will influence the teachers' ways in assisting and motivating to their students and affects the students' learning outcomes.

The pre-service teachers' beliefs are also closely related to their learning experience (Hong \& Chai, 2017). If they were exposed to conventional learning approach during their teacher training, they will tend to develop conventional-learning-oriented beliefs. They tend to believe that students learn better through a detailed process of explanation, comprehensive, and correct information related to mathematical formulas/procedures. Conversely, those who experience discovery learning will build a more constructivist belief.

Pre-service teachers who view mathematics as memorization of facts, procedures and rules, will also encourage the pre-service teachers to emphasis solely on applying the formula, not on conceptual understanding in their teaching later (Beswick, 2005). On the contrary, when the pre-service teachers view mathematics as a process of exploration and problem solving, they will later tend to assist students to explore and construct their understanding of mathematics problems (Hong \& Chai, 2017).

There is an indication that the teachers' beliefs can in many ways influence their teaching later. For example, when they choose or decide which teaching method to use such a method will become their preferred way of teaching (Adnan \& Zakaria, 2010). Thus, understanding pre-service teachers' beliefs is critical in the context of mathematics learning in order to help develop and implement effective mathematics teacher education programs (Barlow \& Reddish, 2006).

There have been a number of studies related to the beliefs of mathematics pre-service teacher but only few that focus on areas of critical thinking learning. Studies conducted both inside and outside Indonesia have put emphasis on teachers' beliefs related to mathematics learning methods (Adnan \& Zakaria, 2010; Didis et al., 2016; Hong \& Chai, 2017; K1lıç, 2011; Lui \& Bonner, 2016). Other studies focus on the impact of teaching methods on the improvement of critical thinking skills (Kurniati et al., 2015; Palinussa, 2013).

In Indonesian context, a research about mathematics pre-service teachers' critical thinking skills by As'ari et al. (2017) brings interesting results. The research shows that the mathematics pre-service teachers in majority are categorized into non-critical thinkers. This portrays that mathematics education in Indonesia has not successfully developed positive beliefs about mathematics learning that can instil critical thinking. What seems to be the flaw of this study is the sample aspect. This study, however, only 
took limited number of sample, thus, the results may not reflect all aspects of pre-service teachers' beliefs on critical thinking. This signifies the need to look at other strategic aspects of pre-service mathematics teacher's beliefs about critical thinking skills.

Previous studies and theoretical underpinning outlined above signify the need to further explore mathematics pre-service teachers' critical thinking skills in more detail and comprehensive study. This study seeks to advance prior research on this topic in two ways. First, this study draws upon the psychological literature to define critical thinking as incorporating both a cognitive (knowledge/skills) component and an affective (dispositional) component (Abrami et al., 2015; Stanovich, 2016). In this view, knowing about and having the skills to analyse arguments, for example, is not sufficient to become a critical thinker. One must also be willing to enthusiastically and habitually apply such knowledge and skills to a variety of everyday situations. The implication for teacher education is that it is important for teachers to develop not only students' critical thinking skills, but also dispositions such as the enjoyment of effortful thinking and the willingness to revise one's prior beliefs/opinions in the face of evidence (Haran et al., 2013). This framework provides a more comprehensive assessment of pre-service teachers' beliefs about critical thinking. Second, more empirically, present study seeks to advance prior research by exploring the potential links between aspects of the teacher training experience with pre-service teachers' personal and pedagogical beliefs about critical thinking. Evidence about such links, or lack thereof, would have important practical implications for mathematics teacher education.

\section{METHOD}

A cross-sectional survey using self-report instruments was conducted to answer the research questions. This method was considered to be appropriate given the study's aim of assessing participants' background and beliefs.

\section{Participants}

Research participants were 223 mathematics pre-service teachers from 3 teacher education institutions in East Java, Indonesia. The research sites were chosen because they represent the most prominent teacher education institutions in the region. Participants were mostly female $(88.6 \%)$, with an age range of 17 to 32 years (averaging 20.72 years). When the data were collected, $44.8 \%$ of the participants were beginning their $3^{\text {rd }}$ semester of undergraduate study, $43.5 \%$ were in their final $6^{\text {th }}$ to $9^{\text {th }}$ semester of undergraduate study, while the remainder were in their first year of a master/graduate degree. They were recruited on a voluntary basis through personal contacts, resulting in a non-random sample. Random sampling was not performed due to practical constraints.

\section{Instruments}

Belief about the value of developing critical thinking was using a scale developed by the second author. The scale asked participants to rate the importance of 7 CT skills (e.g. the ability to present clear arguments) and 5 CT dispositions (e.g. willingness to revise one's opinion based on new evidence) as learning objectives in their future classrooms. The response scale ranged from 0 ("relatively unimportant") to 3 ("essential or very 
important"). The 7 and 5 items were averaged to provide two separate value indices. Internal reliability was 0.63 for the CT skill value index (omitting one item) and 0.65 for the CT disposition value index. In addition, participants were also asked to rate the importance of non-CT related skills and dispositions, which are displayed in Table 2. To gauge the value placed on critical thinking in comparison to other potentially valued learning objectives, participants were asked to choose 3 skills and 3 dispositions (from the list of CT and non-CT related skills/dispositions) they consider to be top priorities in their own future classrooms.

To measure belief about preparedness to teach CT, participants were asked to answer "How sure are you that you are prepared to develop your students' critical thinking in your future class?" on a scale from 0 ("extremely unprepared") to 5 ("very sure that I'm prepared"). Because this was a single item measure, no reliability index was computed.

Preference towards constructivist instruction were assessed using 4 vignettes which depict a teaching dilemma. The vignettes were based on an assessment framework developed by Zohar \& Schwartzer (2005). Vignette A depicted the dilemma of covering the curriculum content vs. going deeper into selected topics, at the risk of neglecting other topics in the curriculum. Vignette B depicted the dilemma of encouraging students to obtain knowledge from teachers and textbooks, vs. encouraging independent exploration and sense making, at the risk of forming conclusions which do not conform to accepted knowledge. Vignette $\mathrm{C}$ was about the dilemma of having students learn only about "certain" and "proven" facts, vs. learning about complex problems and phenomena which do not easily lend themselves to clear, certain answers. Vignette D was about the dilemma of organising the classroom around individual work to emphasise structure and focused attention, vs. incorporating more collaborative and project-based work at the risk of having a "messy" or noisy class. A composite index of preference for constructivist teaching was not computed due to the low internal reliability of the four items.

\section{Analysis}

Descriptive statistics (proportions and means) of the relevant variables were computed to address RQ1 to RQ4. Addressing RQ5, cross tabulations and chi-square tests were performed to examine the associations between different aspects of participants' preservice education with their beliefs about teaching CT and preference for constructivist teaching. For the latter variable, analysis was conducted separately for each teaching dilemma vignette due to the low reliability of the composite index.

\section{FINDINGS}

Q1. The value of critical thinking skills and dispositions as learning objectives: On average, $21.4 \%$ of the study participants placed at least one critical thinking skill as either their first, second, or third priority of learning objectives (see Table 1). This is higher than the average of $15 \%$ who prioritised other (non-CT related) generic skills as learning objectives. Looking more closely at specific skills, three skills were most often endorsed as priority learning objectives. Two critical thinking skills were especially 
popular as prioritised learning objectives: the ability to think independently and to communicate arguments clearly and logically. These are the two critical thinking skills which were endorsed more often than non-CT skills.

On the other hand, four critical thinking skills were relatively unpopular as learning objectives: the ability to comprehend implicit meaning in texts, to evaluate the credibility of information sources, to analyze evidence and claims, and to sinthesize information before making decisions.

Table 1

The Value of CT and non-CT Skills

\begin{tabular}{lllll}
\hline Generic skills (soft skills) & Priority 1 & Priority 2 & Priority 3 & $\begin{array}{l}\text { Priorities } \\
(1,2 \text { or 3) }\end{array}$ \\
\hline Critical thinking skills (average) & $6.9 \%$ & $7.2 \%$ & $7.2 \%$ & $21.4 \%$ \\
Thinking independently & $29.0 \%$ & $10.9 \%$ & $5.0 \%$ & $44.8 \%$ \\
Reflecting on one's own thinking & $6.3 \%$ & $9.1 \%$ & $14.0 \%$ & $29.5 \%$ \\
Arguing clearly and logically & $5.9 \%$ & $16.8 \%$ & $19.5 \%$ & $42.2 \%$ \\
Synthesizing information before making & $2.3 \%$ & $5.0 \%$ & $5.4 \%$ & $12.7 \%$ \\
decisions & & & & $6.3 \%$ \\
Assessing the credibility of the source of & $2.3 \%$ & $1.8 \%$ & $2.3 \%$ & $11.3 \%$ \\
information & $1.4 \%$ & $6.8 \%$ & $3.2 \%$ & $2.7 \%$ \\
Analyzing evidence and evaluating claims & $1.4 \%$ & $0 \%$ & $1.4 \%$ & $15.0 \%$ \\
Analyzing text/implicit meaning & $5.2 \%$ & $5.0 \%$ & $4.9 \%$ & $33.5 \%$ \\
\hline Non-critical thinking skills (average) & $17.6 \%$ & $7.7 \%$ & $8.1 \%$ & $41.7 \%$ \\
Self-regulated learning & $11.8 \%$ & $20.5 \%$ & $9.5 \%$ & $10.9 \%$ \\
Collaboration/teamwork & $5.9 \%$ & $1.4 \%$ & $3.6 \%$ & $18.1 \%$ \\
Persuasive communication & $5.0 \%$ & $5.9 \%$ & $7.2 \%$ & $16.8 \%$ \\
Understanding of many facts/information & $4.5 \%$ & $4.1 \%$ & $8.1 \%$ & $10.0 \%$ \\
Foreign language proficiency & $2.7 \%$ & $4.1 \%$ & $3.2 \%$ & $12.2 \%$ \\
Competency in subject matters & $0.9 \%$ & $4.1 \%$ & $7.2 \%$ & $4.5 \%$ \\
Test-taking skills & $0.9 \%$ & $1.8 \%$ & $1.8 \%$ & $0 \%$ \\
Explaining social phenomena & $0 \%$ & $0 \%$ & $0 \%$ & \\
Explaining natural phenomena & & & & \\
\hline
\end{tabular}

With regards to dispositions, on average only $12.8 \%$ of the participants endorsed at least one critical thinking disposition, in comparison to $39.3 \%$ who endorsed non-CT dispositions as their prioritised learning objective. Looking at the specific dispositions, three non-CT dispositions were especially popular as learning objectives, mentioned by around $50 \%$ or more of the participants as prioritsed learning objectives. These were respect towards teachers and parents, religiousity, self-discipline. The two most popular CT-related dispositions, willingness to revise one's opinion and to think systematically and reflectively, were only mentioned as prioritised learning objectives by around $20 \%$ of the participants. 
Table 2

The Value of CT and non-CT Dispositions

\begin{tabular}{lllll}
\hline Dispositions/characters & Priority 1 & Priority 2 & Priority 3 & $\begin{array}{l}\text { Priorities } \\
(1,2 \text { or 3) }\end{array}$ \\
\hline Critical thinking dispositions (average) & $2.3 \%$ & $4.7 \%$ & $5.8 \%$ & $12.8 \%$ \\
Enjoys thinking about abstract ideas & $5.0 \%$ & $2.7 \%$ & $2.3 \%$ & $10.0 \%$ \\
Willing to revise opinion & $2.7 \%$ & $7.7 \%$ & $8.6 \%$ & $19.0 \%$ \\
Preference for careful, reflective thinking & $2.3 \%$ & $7.7 \%$ & $10.5 \%$ & $20.4 \%$ \\
Seek and value evidence which contradict & $1.4 \%$ & $3.6 \%$ & $6.4 \%$ & $11.3 \%$ \\
personal preference & $0 \%$ & $1.8 \%$ & $1.4 \%$ & $3.2 \%$ \\
Enjoys deep, effortful cognitive activities & $14.8 \%$ & $12.7 \%$ & $11.8 \%$ & $39,3 \%$ \\
Non-critical thinking dispositions (average) & $42.5 \%$ & $20.8 \%$ & $17.7 \%$ & $81.1 \%$ \\
Respect for teachers and parents & $23.1 \%$ & $17.6 \%$ & $8.6 \%$ & $49.4 \%$ \\
Being religious & $20.4 \%$ & $20.8 \%$ & $20.5 \%$ & $61.6 \%$ \\
Discipline and self-control & $2.7 \%$ & $14.5 \%$ & $19.5 \%$ & $36.7 \%$ \\
Perseverance & $0 \%$ & $1.4 \%$ & $3.2 \%$ & $4.5 \%$ \\
Obedience to authority and law & & & & \\
\hline
\end{tabular}

Q2. Perceived preparedness to teach for critical thinking: Almost $60 \%$ of the participants reported being either "sure" or "very sure" that they are ready to develop their students' critical thinking in class.

Table 3

Pre-service Teachers' Perceptions on Preparedness to Teach CT

\begin{tabular}{lll}
\hline Perceived preparedness & $F$ & $\%$ \\
\hline Extremely unprepared & 0 & 0 \\
Unprepared & 6 & 2.9 \\
Unsure whether prepared or not & 80 & 39.0 \\
Prepared & 102 & 49.8 \\
Very sure prepared & 17 & 8.3 \\
\hline Total & 205 & 100 \\
\hline
\end{tabular}

Responses to the open-ended question reveal some of the reasons underlying the participants' belief about their lack of preparedness. Some of these responses cited their limited knowledge about critical thinking and how to teach for it. Sometimes these responses mentioned specific skills like: "I have not had the opportunity to create test items to assess students' higher order thinking" and "I don't know how to write tasks which call for critical thinking." Others cited their lack of practical teaching experience by writing statements such as "I have not yet implemented [critical thinking teaching] in a real class."

Q3. Preference for constructivist teaching approaches: Between $57 \%$ to $67 \%$ of the participants were in favour of constructivist approaches in response to 3 of the 4 teaching dilemmas (see Table 4). However, only $14 \%$ preferred the constructivist approach in response to Dilemma $\mathrm{C}$, which focuses on the certainty or uncertainty of knowledge as an object of learning. 
Table 4

Teaching Dilemma and Preference for Teaching Approaches

\begin{tabular}{|c|c|c|c|c|}
\hline \multirow{2}{*}{ Teaching Dilemma } & \multicolumn{2}{|c|}{ Traditional Instruction } & \multicolumn{2}{|c|}{ Constructivist Instruction } \\
\hline & $f$ & $\%$ & $f$ & $\%$ \\
\hline $\begin{array}{l}\text { Coverage of curricular content (traditional) vs. going } \\
\text { deep at the risk of neglecting some curricular } \\
\text { content (constructivist). }\end{array}$ & 90 & 41.5 & 127 & 58.5 \\
\hline $\begin{array}{l}\text { Obtain knowledge from teachers/authorities } \\
\text { (traditional) vs. independent exploration, at the risk } \\
\text { of reaching wrong conclusions (constructivist). }\end{array}$ & 92 & 42.6 & 124 & 57.4 \\
\hline $\begin{array}{l}\text { Learning about "proven" facts/concepts (traditional) } \\
\text { vs. learning about complex phenomena/problems } \\
\text { without certain answers (constructivist). }\end{array}$ & 180 & 85.3 & 31 & 14.7 \\
\hline $\begin{array}{l}\text { Quiet and focused class with students working } \\
\text { individually (traditional) vs. having students engage } \\
\text { in argumenation and collaborations, at the risk of } \\
\text { having a "messy" and "noisy" class (constructivist). }\end{array}$ & 66 & 32.4 & 138 & 67.6 \\
\hline
\end{tabular}

It is important to note that the low internal reliability of responses to these four dilemmas indicates that different facets of constructivist instruction evoke different preferences. In other words, preference for instructional approach seems to be fragmented and contextual. Pre-service teachers who endorse the use of argumentation and collaborative learning (Dilemma D), for example, may simultaneously give more emphasis to content coverage than in-depth understanding (Dilemma A), or vice-versa.

Q4. Exposure to critical thinking in pre-service training: Most participants have not attended seminars or workshops on critical thinking outside of the normal coursework (see Table 5). Most also have not read books or other materials about the topic. However, when asked about their coursework experience, most report that they have had at least one course which developed their critical thinking skills and pedagogical knowledge about teaching CT.

Table 5

Course Experience on CT Skills Development

\begin{tabular}{|c|c|c|c|c|}
\hline No. & $\begin{array}{l}\text { During the course of your pre-service education, have } \\
\text { you ... }\end{array}$ & Answer & $f$ & $\%$ \\
\hline \multirow[t]{2}{*}{1.} & \multirow{2}{*}{$\begin{array}{l}\text { attended seminars/workshop on critical thinking as } \\
\text { part of your pre-service teacher education? }\end{array}$} & No & 145 & 65.9 \\
\hline & & Yes & 75 & 34.1 \\
\hline \multirow[t]{2}{*}{2.} & \multirow{2}{*}{$\begin{array}{l}\text { attended seminars/workshop on critical thinking which } \\
\text { is beyond/external to your pre-service teacher } \\
\text { education? }\end{array}$} & No & 205 & 95.8 \\
\hline & & Yes & 9 & 4.2 \\
\hline \multirow[t]{2}{*}{3.} & \multirow[t]{2}{*}{ read articles or books about critical thinking? } & No & 135 & 63.1 \\
\hline & & Yes & 79 & 36.9 \\
\hline \multirow[t]{3}{*}{4.} & \multirow{3}{*}{$\begin{array}{l}\text { taken any coursework (as part of your pre-service } \\
\text { education program) which develops your own critical } \\
\text { thinking? }\end{array}$} & No & 17 & 8.0 \\
\hline & & Unsure & 19 & 8.9 \\
\hline & & Yes & 177 & 83.1 \\
\hline \multirow[t]{3}{*}{5.} & \multirow{3}{*}{$\begin{array}{l}\text { taken any coursework (as part of your pre-service } \\
\text { education program) which develops your pedagogical } \\
\text { knowledge to teach for critical thinking? }\end{array}$} & No & 9 & 4.5 \\
\hline & & Unsure & 16 & 7.9 \\
\hline & & Yes & 177 & 87.6 \\
\hline
\end{tabular}


Q5. Relationships between beliefs, course experience, and preference of teaching approaches: The regression results indicate that aspects of the participants' pre-service education are mostly unrelated to their beliefs about CT and instructional preferences (see Table 6). When they were related, the associations were weak. More specifically, when belief about the value of teaching for CT skills was regressed on the pre-service experience variables, the overall model was significant $(\mathrm{R}=0.284 ; \mathrm{p}=0.022)$. Looking at the individual variables, only two were considered to be significant predictors: level of study and coursework which develop one's own CT.

With regards to beliefs about preparedness to teach for CT, the overall model was also significant $(\mathrm{R}=0.328 ; \mathrm{p}=0.003)$. However, only one variable was considered to be significantly associated with this belief: experience with coursework which develops pedagogical knowledge. Meanwhile, the overall regression model for belief about the value of teaching for CT dispositions was non-significant $(R=0.210 ; p=0.244)$.

Table 6

Result of Regression Analysis on the Relation among Beliefs, Course Experience, and Preference for Teaching Approaches

\begin{tabular}{|c|c|c|c|c|c|c|c|}
\hline \multirow[t]{3}{*}{ No. } & \multirow{3}{*}{$\begin{array}{l}\text { Aspects of pre-service } \\
\text { experience (predictor } \\
\text { variables) } \\
\text { (Constant) }\end{array}$} & \multicolumn{2}{|c|}{$\begin{array}{l}\text { Value of CT skills } \\
\text { as learning objective }\end{array}$} & \multicolumn{2}{|c|}{$\begin{array}{l}\text { Value of CT } \\
\text { dispositions as } \\
\text { learning objective }\end{array}$} & \multicolumn{2}{|c|}{$\begin{array}{l}\text { Confidence in } \\
\text { teaching for CT }\end{array}$} \\
\hline & & $\mathrm{B}$ & sig. & $\mathrm{B}$ & sig. & $\mathrm{B}$ & sig. \\
\hline & & 2.546 & .000 & 2.678 & .000 & 1.563 & .000 \\
\hline 1. & Level of study & .144 & .011 & .063 & .222 & .102 & .215 \\
\hline 2. & $\begin{array}{l}\text { Attended CT seminars/ } \\
\text { workshop as part of pre-service } \\
\text { education }\end{array}$ & -.051 & .531 & -.094 & .200 & .084 & .477 \\
\hline 3. & $\begin{array}{l}\text { Attended CT } \\
\text { seminars/workshop } \\
\text { beyond pre-service education }\end{array}$ & .132 & .456 & -.101 & .529 & .176 & .520 \\
\hline 4. & $\begin{array}{l}\text { Read articles or books about } \\
\text { CT }\end{array}$ & -.045 & .566 & .093 & .199 & -.130 & .255 \\
\hline 5. & $\begin{array}{l}\text { Coursework which develops } \\
\text { your own CT }\end{array}$ & .081 & .035 & .052 & .136 & .067 & .232 \\
\hline 6. & $\begin{array}{l}\text { Coursework which develops } \\
\text { pedagogical knowledge to } \\
\text { teach for CT }\end{array}$ & .049 & .262 & .009 & .820 & .210 & .001 \\
\hline
\end{tabular}

With regards to teaching preferences, chi-square tests indicate that three aspects of preservice education were associated with greater preference for at least one aspect of constructivist teaching (see Table 7). First, pre-service teachers studying at the postgraduate level were more likely than undergraduate students to prefer constructivist approaches related to aiming for deeper understanding (Dilemma A) and independent exploration (Dilemma B). Second, pre-service teachers who reported of having read books or other materials on critical thinking were more likely to prefer constructivist teaching related to aiming for deeper understanding (Dilemma A). Third, those who reported of having attended at least one coursework which developed their critical thinking were also more likely to prefer constructivist teaching approaches related to Dilemmas A and B. 
Table 7

Preference for Teaching Approaches

\begin{tabular}{|c|c|c|c|c|c|c|c|c|c|}
\hline \multirow{2}{*}{$\begin{array}{l}\text { Aspects of Pre- } \\
\text { service Education }\end{array}$} & & \multicolumn{2}{|c|}{ Teaching Dilemma A } & \multicolumn{2}{|c|}{ Teaching Dilemma B } & \multicolumn{2}{|c|}{ Teaching Dilemma C } & \multicolumn{2}{|c|}{ Teaching Dilemma $\mathrm{D}$} \\
\hline & & Trad. & Const. & Trad. & Const. & Trad. & Const. & Trad. & Const. \\
\hline \multirow[t]{3}{*}{ 1. Level of study } & Underg. sophomores & $52.2 \%$ & $38.6 \%$ & $54.3 \%$ & $37.1 \%$ & $43.9 \%$ & $54.8 \%$ & $43.9 \%$ & $46.4 \%$ \\
\hline & Underg. Seniors & $42.2 \%$ & $44.9 \%$ & $38.0 \%$ & $47.6 \%$ & $46.1 \%$ & $25.8 \%$ & $43.9 \%$ & $40.6 \%$ \\
\hline & Postgraduates & $5.6 \%$ & $16.5 \%$ & $7.6 \%$ & $15.3 \%$ & $10.0 \%$ & $19.4 \%$ & $12.1 \%$ & $13.0 \%$ \\
\hline \multirow{2}{*}{$\begin{array}{l}\text { 2. Attended CT } \\
\text { seminars } \\
\text { /workshop as part } \\
\text { of pre-service } \\
\text { education }\end{array}$} & No & $68.9 \%$ & $63.2 \%$ & $64.8 \%$ & $67.5 \%$ & $63.5 \%$ & $77.4 \%$ & $71.2 \%$ & $64.7 \%$ \\
\hline & Yes & $31.1 \%$ & $36.8 \%$ & $35.2 \%$ & $32.5 \%$ & $36.5 \%$ & $22.6 \%$ & $28.8 \%$ & $35.3 \%$ \\
\hline \multirow{2}{*}{$\begin{array}{l}\text { 3. Attended CT } \\
\text { seminars/ } \\
\text { workshop beyond } \\
\text { pre-service } \\
\text { education }\end{array}$} & No & $96.6 \%$ & $95.8 \%$ & $96.6 \%$ & $95.0 \%$ & $96.0 \%$ & $96.8 \%$ & $93.7 \%$ & $98.5 \%$ \\
\hline & Yes & $3.4 \%$ & $4.2 \%$ & $3.4 \%$ & $5.0 \%$ & $4.0 \%$ & $3.2 \%$ & $6.3 \%$ & $1.5 \%$ \\
\hline 4. Read articles or books & No & $77.0 \%$ & $54.9 \%$ & $66.3 \%$ & $62.5 \%$ & $63.6 \%$ & $60.0 \%$ & $54.1 \%$ & $65.9 \%$ \\
\hline thinking & Yes & $23.0 \%$ & $45.1 \%$ & $33.7 \%$ & $37.5 \%$ & $36.4 \%$ & $40.0 \%$ & $45.9 \%$ & $34.1 \%$ \\
\hline \multirow{3}{*}{$\begin{array}{l}\text { 5. Course work which } \\
\text { develops your } \\
\text { own critical } \\
\text { thinking }\end{array}$} & No & $10.5 \%$ & $5.0 \%$ & $4.5 \%$ & $10.9 \%$ & $8.1 \%$ & $3.3 \%$ & $3.1 \%$ & $9.2 \%$ \\
\hline & Yes & $75.6 \%$ & $89.3 \%$ & $79.5 \%$ & $84.9 \%$ & $83.1 \%$ & $90.0 \%$ & $85.9 \%$ & $82.4 \%$ \\
\hline & Unsure & $14.0 \%$ & $5.8 \%$ & $15.9 \%$ & $4.2 \%$ & $8.7 \%$ & $6.7 \%$ & $10.9 \%$ & $8.4 \%$ \\
\hline \multirow{3}{*}{$\begin{array}{l}\text { 6. Course work which } \\
\text { develops } \\
\text { pedagogical } \\
\text { knowledge to } \\
\text { teach for critical } \\
\text { thinking }\end{array}$} & No & $3.7 \%$ & $5.2 \%$ & $4.8 \%$ & $3.5 \%$ & $4.3 \%$ & $6.7 \%$ & $5.0 \%$ & $3.9 \%$ \\
\hline & Yes & $88.9 \%$ & $87.1 \%$ & $83.1 \%$ & $91.2 \%$ & $89.5 \%$ & $80.0 \%$ & $85.0 \%$ & $88.3 \%$ \\
\hline & Unsure & $7.4 \%$ & $7.8 \%$ & $12.0 \%$ & $5.3 \%$ & $6.2 \%$ & $13.3 \%$ & $10.0 \%$ & $7.8 \%$ \\
\hline
\end{tabular}

\section{DISCUSSION}

RQ1: Overall, mathematics pre-service teachers in this study believed in the importance of developing students critical thinking skills. This belief arises because the mathematics has been learned since elementary school and because critical thinking skills and mathematics are inseparable. Mathematics material can be well understood through critical thinking and critical thinking can be trained through learning mathematics (Fonseca \& Arezes, 2017). Thus, they are accustomed to the critical way of thinking along with their mathematics learning.

In addition, since 2015 all teacher education institutions have conducted the revitalization of curriculum in the form of National Curriculum Framework of Indonesia (NCFI). With NCFI, teacher education institutions are encouraged to design and provide learning environment and assessment that can improve critical thinking skills of teacher candidates (Kemendikbud, 2014).

Comparatively, skills related to critical thinking were deemed more important (on average) than other generic skills such as team work and persuasive communication. Two critical thinking skills were deemed particularly important: the ability to think independently and to present clear, logical arguments. These are encouraging results, considering teachers' choice of learning objectives in their lesson planning can have important influences in how they teach. For Lee \& Takahashi (2011), the formulation of learning objectives is very important as a reference for teachers in designing learning materials. Interaction between teachers and students in the classroom during the learning 
process is influenced by how the learning objectives are formulated. Thus, the formulation of learning objectives by the teachers will represent what mathematics material students should learn and what learning process teachers expect.

However, there seems to be a gap between beliefs about the value of teaching skills on the one hand, and dispositions on the other. CT dispositions such as willingness to revise one's belief/opinion were seen as much less important than non-CT dispositions such as religiosity and respect towards elders. This gap needs to be addressed, because dispositions are an essential part of critical thinking. In other words, being a critical thinker means having both a set of skills and the dispositions to apply to skills. A student who knows how to evaluate and compose strong arguments, for example, would mean little if she/he lacks the motivation to use that knowledge when necessary.

The comparative lack of value attached to CT dispositions is a matter of concern, because such dispositions are essential part of being a critical thinker (Abrami et al., 2015). In the context of teaching, teachers need to possess critical thinking disposition to enable them to present or teach critical thinking to their students (Sendag \& Erol, 2015). Critical thinking dispositions are perceived as triggers, motivators and incentives to be skillful and accustomed to critical thinking (Sahin et al, 2016). In the context of mathematics teacher education, developing a critical thinking disposition will shape curiosity, awareness, dedication and a strong tendency for pre-service teachers to think and do mathematically in a positive way.

In mathematics, critical thinking takes the form of ways of thinking that put forward deductive processes. Through deductive thinking, a coherent and logical frame of mind can be established. This kind of thinking, requires a student who is studying mathematics to mobilize his ability in reasoning, to analyze and interpret his thinking in order to be able to understand and solve commonly abstract mathematics problems (in the form of facts, concepts, principles or skills).

These activities also require students to adopt certain dispositions such as persistence, diligence and constant focus on mathematics problems encountered and seek to find a solution. In their search for solutions, they need to plan problem-solving strategies from various sources (exploration), put ideas into solutions, compare solutions strategies with prior experience, and identify their relevance. When the solution is selected, they need to construct or, if necessary, reconstruct the idea before making a conclusion. This stage requires a confident attitude to the inquiry process in the discovery of a solution that is believed to be true. However, it also takes a willingness to acknowledge the mistake when there are less appropriate steps and solutions and to turn change them into correct solution.

RQ2: Results of this study indicate that most pre-service mathematics teacher believed they were ready to teach for CT. Even so, the results also indicate that many (more than $40 \%$ ) feel unsure about their readiness to teach for critical thinking. Beliefs about readiness to teach can be seen as part of a teachers' teaching self-efficacy. This is because teachers with high self-efficacy will be able to facilitate students' learning despite students' difficulties and lack of motivation (Bandura, 1977). They are more 
open in adopting new learning practices. Findings by Flores \& Clark (2004) and Matthews at al. (2003) signify that teachers' self-efficacy in teaching influences teachers' communication styles, motivations, teachers' emotions while teaching, and teachers' patience in dealing with students with problems. Fung et al. (2017) also states that teachers' efficacy affects the way they teach and interact in the classroom which then affects the student's mathematics learning outcomes.

Qualitative responses indicate that lack of readiness may stem from a lack of pedagogical content knowledge on the teaching of critical thinking. One of causes is that lecturers only give chunks when facilitating mathematics pre-service teachers' understanding on critical thinking, i.e., the lecturers teach 'quasi-critical thinking' (Ab Kadir, 2017).

An effective way to train critical thinking skills to mathematics pre-service teachers according to Akınoğlu \& Karsantık (2016) is through modelling. Modelling can not only encourage the positive behavior of mathematics pre-service teachers in developing critical thinking skills but also develop their ways to teach critical thinking as the skills they must have in their teaching career later. Gelder (2005) confirms that pre-service teachers must have the ability to teach critical thinking, need to exercise regularly and constantly improve their critical thinking skills.

Considering the above issue, it is significant to facilitate pre-service teachers to have special knowledge and skills related to critical thinking pedagogical content knowledge (PCKCT). That is the knowledge of what critical thinking is, how and when to apply and integrate that knowledge into teaching material effectively (Ab Kadir, 2017). Therefore, providing PCKT during teacher education is fundamental. Without basic knowledge of adequate PCKT, it is very likely that they will continue to have lack of confidence and doubt in teaching critical thinking. Skilling et al. (2016) states that the experience of pre-service teachers in their teacher education will influence the way they teach later.

RQ3: Table 7 shows variation between participants in preference towards constructivist teaching, with about $40 \%$ preferring traditional approaches. This finding confirms previous finding of the lack of readiness of pre-service teachers to teach critical thinking. This is supposedly influenced by their experience during their coursework. Hong \& Chai (2017) state that if their learning experience during the coursework is more on a conventional learning approach, they will develop more conventionaloriented beliefs. They will develop the belief that learning mathematics will succeed through a detailed process of explanation, comprehensive, and correct information related to mathematics formulas/ procedures. This can result from of lack experience of discovery learning and less opportunity provided by lecturers for self-exploration of given mathematics problems.

There is also variation across contexts or situations from the aspect of pre-service teacher education. Pre-service teachers were more willing to adopt constructivist approaches with regards to using collaboration, encouraging independent exploration, and deep learning (over content coverage). This is because they view these three capabilities crucial skills in critical thinking. 
The research data shows that the above three aspects are achieved well by those who have the experience of reading, attending seminars / workshops related to critical thinking and better education. This finding is relevant to Kahan et al. (2003) opinion that the more reading and attending seminars/workshops in the field of critical thinking will stimulate wider perspectives so as to encourage understanding of the constructivist approach.

This group of pre-service teachers also increasingly see the importance of deep understanding of mathematics concepts and materials (Adler et al., 2014). This is characterized by the ability to make interrelationships between concepts and procedures and operations in mathematics. In addition, more frequent reading of books or attending seminars/workshops make them aware of the need for collaborative work in solving mathematics problems (O'Shea \& Leavy, 2013). They think that the mathematics problems, mainly those that require the ability to think critically in the process of finding solution, are too difficult to be solve independently. Thus, collaborative work is regarded as a necessity. This is an important aspect of learning that can trigger a constructivist perspective.

One particular form of constructivist teaching which was unpopular concerned learning about unstructured and complex problems which do not have certain answers. This is due to their unfamiliarity with mathematics problems that require critical thinking skills (Nursyahidah \& Albab, 2017). It should be suspected that mathematics problems often given during school and college only require more ability to apply formulas, procedures or algorithms. Once confronted with questions about unstructured and complex mathematics problems that require divergent answers, they seem to experience a shock. In fact, unstructured and complex mathematics problems can strengthen their critical thinking dispositions, thereby encouraging their sensitivity to critical thinking and the tendency to engage in critical thinking learning practices.

RQ4: The pattern of response suggests that for most participants, exposure to critical thinking knowledge and pedagogy is limited by what is available in their standard coursework. This further emphasizes the previous explanation that the coursework is still dominated by lectures (Iman, 2017). There are less opportunities for pre-service teachers to explore their skills (either independently or collaboratively) by providing more mathematics problems that require reasoning, analysis, evaluation and thinking interpretation to trigger the emergence of skills or critical thinking teaching experience.

The logical consequence of the above phenomenon is that few have sought to enrich their CT knowledge through independent study or from sources beyond their normal coursework. This can reflect that disposition of critical thinking has not yet been internalized in pre-service teachers. In this context, the disposition of critical thinking of curiosity to obtain information and learning new things is still low. Meanwhile, curiosity is important because it affects them in accepting various things including new learning approaches that encourage the development of critical thinking.

RQ5: Table 1 and previous elaboration show that some aspects of the pre-service education seem to contribute positively to cultivating the belief that CT skills need to be 
taught, such as ability to synthesize information, to assess the credibility of source of information and to analyze evidence. But pre-service education seems to have little bearing on beliefs about the value of teaching for CT dispositions, and on preferences towards constructivist instruction.

Some important things to do to reform the learning in the teacher education institute to enhance the ability of critical thinking: (a) the lecturers should change the dominance of the lecturing in the learning process in order to provide more opportunities for preservice teachers to ask questions, explore their skills, argue, discuss with friends. It is expected that such opportunities can develop pre-service teachers' potential and critical thinking skills, (b) the lecturers should always provide non-routine questions or tasks related to the real world and relate to daily life that will train pre-service teachers to think deeply, and ( c) pre-service teachers should be provided with knowledge and specific skills related to adequate critical thinking pedagogy content knowledge, that is the knowledge of what critical thinking is, how and when to apply and integrate that knowledge into the practice of teaching materials effectively.

\section{CONCLUSION AND LIMITATION}

This research aims to explore the beliefs of mathematics pre-service teachers in Indonesia related to the ability to think critically and their implications on several aspects in the selection of learning approaches. Some important points of this research are highlighted as follows. Participants believed that some CT skills (thinking independently and logical communication) were important, but CT dispositions were not. About $60 \%$ believed they are prepared to teach CT and generally preferred constructivist over traditional instruction. Some aspects of the pre-service education were not associated with pedagogical beliefs about CT disposition, perceived preparedness, or preference for constructivist instruction (and only weakly associated with associated with belief about teaching CT skills). This highlights the need for mathematics teacher educators to give more emphasis on the importance of CT, especially its dispositional dimensions, and the role of constructivist instruction in developing CT.

\section{REFERENCES}

Ab Kadir, M. A. (2017). What teacher knowledge matters in effectively developing Critical Thinkers in the 21 st Century Curriculum? Thinking Skills and Creativity, 23(1), 79-90.

Ab Kadir, M. A. (2015). Developing critical thinkers in $21^{\text {st }}$ century: Gap in teacher education? In K.M. Baharul Islam and S.N. Iftekhar (Ed), International Perspectives on Comparative Education Policy (pp. 330-342). New Delhi: Bloomsbury

Abrami, P. C.; Bernard, R. M.; Borokhovski, E.; Waddington, D. I.; Wade, C. A. \& Persson, T. (2015). Strategies for teaching students to think critically: A meta-analysis. Review of Educational Research, 85(2), 275-314.

Adler, J.; Hossain, S.; Stevenson, M.; Clarke, J.; Archer, R. \& Grantham, B. (2014). Mathematics for teaching and deep subject knowledge: voices of Mathematics 
Enhancement Course students in England. Journal of Mathematics Teacher Education 17. 129-148.

Adnan, M. \& Zakaria, E. (2010). Exploring beliefs of pre-service mathematics teachers : A malaysian perspective. Asian Social Science, 6(2), 152-158.

Akınoğlu, O., \& Karsantık, Y. (2016). Pre-service teachers' opinions on teaching thinking skills. International Journal of Instruction, 9(2), 61-76.

As'ari, A. R.; Mahmudi, A. \& Nuerlaelah, E. (2017). Our prospective mathematic teachers are not critical thinker yet. Journal on Mathematics Education, 8(2), 145-156.

Bandura, A. (1977). Self-efficacy: Toward a unifying theory of behavioral change. Psychological Review, 84(2), 191-215.

Barlow, A. T., \& Reddish, J. M. (2006). Mathematical myths: Teacher candidates' beliefs and the implications for teacher educators. Teacher Educator 41.145-147.

Berliner, D. C. (2009). Rational response to high-stakes testing and the special case of narrowing the curriculum. In International Conference on Redesigning Pedagogy, National Institute of Education, Nanyang Technological University, June. 113.

Beswick, K. (2005). The beliefs/practice connection in broadly defined contexts. Mathematics Education Research Journal, 17(22), 39-68.

Cooney, T. J. (2001). Considering the paradoxes, perils, and purposes of conceptualizing theacher development. In F.L. Lin (Ed.), Making sense of mathematics teacher education (pp. 9 -31). Dordrecht: Kluwer.

Dewantara, A. H.; Zulkardi \& Darmawijoyo. (2015). Assessing seventh graders' mathematical literacy in solving PISA-Like tasks. Journal on Mathematics Education, 6(2), 117-128.

Didis, M. G.; Erbas, A. K.; Cetinkaya, B.; Cakiroglu, E. \& Alacaci, C. (2016). Exploring prospective secondary mathematics teachers' interpretation of student thinking through analysing students' work in modelling. Mathematics Education Research Journal 28. 349-378.

Flores, B. B., \& Clark, E. R. (2004). A critical examination of normalistas' selfconceptualization and teacher-efficacy. Hispanic Journal of Behavioral Sciences 26. 230-257.

Fonseca, L., \& Arezes, S. (2017). A didactic proposal to develop critical thinking in mathematics : The case of Tomás. Journal of the European Teacher Education Network $12.37-48$.

Fung, D., Kutnick, P., Mok, I., Leung, F., Pok-Yee Lee, B., Mai, Y. Y., \& Tyler, M. T. (2017). Relationships between teachers' background, their subject knowledge and pedagogic efficacy, and pupil achievement in primary school mathematics in Hong Kong: An indicative study. International Journal of Educational Research 81.119-130. 
Gelder, T. van. (2005). Teaching critical thinking: Some lessons from cognitive science. College Teaching, 53(1), 41-48.

Grootenboer, P. (2008). Mathematical belief change in prospective primary teachers. Journal of Mathematics Teacher Education, 11(6), 479-497.

Hallman-Thrasher, A. (2017). Prospective elementary teachers' responses to unanticipated incorrect solutions to problem-solving tasks. Journal of Mathematics Teacher Education, 20(6), 519-555.

Hammerness, K.; Darling-Hammond, L.; Bransford, J.; Berliner, D.; Cochran-Smith; M., McDonald, M., \& Zeichner, K. (2005). How teachers learn and develop. In L. Darling-Hammond (Ed.), Preparing teachers for a changing world: What teachers should learn and be able to do (pp. 358-389). San Francisco, CA: John Wiley \& Sons.

Haran, U., Ritov, I., \& Mellers, B. A. (2013). The role of actively open-minded thinking in information acquisition, accuracy, and calibration. Judgment and Decision Making, $83,188-201$.

Hong, H.Y., \& Chai, C.S. (2017). Principle-based design: Development of adaptive mathematics teaching practices and beliefs in a knowledge building environment. Computers \& Education 115. 38-55.

Iman, J. N. (2017). Debate instruction in EFL classroom: Impacts on the critical thinking and speaking skill. International Journal of Instruction, 10(4), 87-108.

Innabi, H., \& El Sheikh, O. (2007). The change in mathematics teachers' perceptions of critical thinking after 15 years of educational reform in Jordan. Educational Studies in Mathematics 64. 45-68.

Kahan, J. A, Cooper, D. A, \& Bethea, K. A. (2003). The role of mathematics teachers' content knowledge in their teaching: A framework for research applied to a study of student teachers. Journal of Mathematics Teacher Education 6. 223-252.

Kemendikbud (2014). Buku kurikulum pendidikan tinggi [The book of higher education curriculum]. Jakarta, Indonesia: Direktorat Pembelajaran dan Kemahasiswaan, Direktorat Pendidikan Tinggi, Kementerian Pendidikan dan Kebudayaan.

Kılıç, H. (2011). Preservice secondary mathematics teachers' knowledge of students. Turkish Online Journal of Qualitative Inquiry, 2(2), 17-35.

Kurniati; Kusumah, Y. S.; Sabandar, J., \& Herman, T. (2015). Mathematical critical thinking ability through contextual teaching and learning approach. Journal on Mathematics Education, 6(1), 53-62.

Lailiyah, S.; Nusantara, T.; Sa'Dijah, C.; Irawan, E. B.; Kusaeri, \& Asyhar, A. H. (2018). Structuring students' analogical reasoning in solving algebra problem. In IOP Conference Series: Materials Science and Engineering. 296(1), p. 012029.

Lee, C. W., Walkowiak, T. A., \& Nietfeld, J. L. (2017). Characterization of mathematics instructional practises for prospective elementary teachers with varying 
levels of self-efficacy in classroom management and mathematics teaching. Mathematics Education Research Journal, 29(1), 45-72.

Lee, Y. A., \& Takahashi, A. (2011). Lesson plans and the contingency of classroom interactions. Human Studies, 34(2), 209-227.

Lui, A. M., \& Bonner, S. M. (2016). Preservice and inservice teachers' knowledge, beliefs, and instructional planning in primary school mathematics. Teaching and Teacher Education. Teaching and Teacher Education 56.1-13.

Matthews, G., Deary, I. J., \& Whiteman, M. C. (2003). Personality traits, Second Edition. Cambridge, NY: Cambridge University Press.

Nursyahidah, F., \& Albab, I. U. (2017). Investigating student difficulties on integral calculus based on critical thinking aspects. Jurnal Riset Pendidikan Matematika, 4(2), 211-218.

O’Shea, J., \& Leavy, A. M. (2013). Teaching mathematical problem-solving from an emergent constructivist perspective: The experiences of Irish primary teachers. Journal of Mathematics Teacher Education, 16(4), 293-318.

Oktiningrum, W., \& Hartono, Y. (2016). Developing Pisa-Like mathematics task with Indonesia natural and cultural heritage as context to assess students' mathematical literacy. Journal on Mathematics Education, 7(1), 1-8.

Palinussa, A. L. (2013). Students' critical mathematical thinking skills and character: experiments for junior high school students through realistic mathematics education culture-based. Journal on Mathematics Education, 4(1), 75-94.

Prahmana, R.C.I., Zulkardi, Z., \& Hartono,Y. (2012). Learning multiplication using Indonesian traditional game in third Grade. Journal on Mathematics Education, 3(2), 115-132.

Richardson, V., \& Placier, P. (2001). Teacher change. In V. Richardson (Ed.), Handbook of research on teaching. Washington, DC: American Educational Research Association.

Sahin, S. A., Tunca, N., Altinkurt, Y., \& Yilmaz, K. (2016). Relationship between professional values and critical thinking disposition of science-technology and mathematics teachers. Eurasia Journal of Mathematics, Science \& Technology Education, 12(1), 25-40.

Sembiring, R. K., Hadi, S., \& Dolk, M. (2008). Reforming mathematics learning in Indonesian classrooms through RME. ZDM-International Journal on Mathematics Education 40. 927-939.

Sendag, S., Erol, O., Sezgin, S. \& Dulkadir, N. (2015). Pre-service teachers' critical thinking dispositions and Web 2.0 competencies. Contemporary Educational Technology, 6(3) 172-187

Skilling, K.; Bobis, J.; Martin, A. J.; Anderson, J., \& Way, J. (2016). What secondary 
teachers think and do about student engagement in mathematics. Mathematics Education Research Journal 28: 545-566.

Stanovich, K. E. (2016). The comprehensive assessment of rational thinking. Educational Psychologist, 51(1), 23-34.

Staples, M. E., \& Truxaw, M. P. (2012). An initial framework for the language of higher-order thinking mathematics practices. Mathematics Education Research Journal, 24(3), 257-281.

Zohar, A., \& Schwartzer, N. (2005). Assessing teachers' pedagogical knowledge in the context of teaching higher-order thinking. International Journal of Science Education, 27(13), 1595-1620. 